\title{
SURFACE CHARACTERIZATION OF COMMERCIALLY PURE TITANIUM AND TITANIUM ALLOY AFTER MECHANICAL STRESSES AND FLUORIDE APPLICATION
}

\author{
Dalia I El-Korashy* and Mohammed S Nassif*
}

\begin{abstract}
Objectives: To characterize topographically and chemically, the surface of commercially pure titanium (CpTi) and titanium aluminum vanadium (Ti-6Al-4V) alloy after mechanical stresses, fluoride application and their combined effect.
\end{abstract}

Methods: CpTi and Ti-6Al-4V alloy cylinders $6 \mathrm{~mm}$ in diameter and $8 \mathrm{~mm}$ in length were used in this study. The specimens were grouped according to the treatment applied into 5 experimental groups; group I included the as-received cylinders; group II included specimens that were immersed in artificial saliva for 28 days; in group III, specimens were subjected to 50,000 cycles of $100 \mathrm{~N}$ axial loading under compression while immersed in artificial saliva; group IV included specimens that were immersed in artificial saliva containing $1500 \mathrm{ppm}$ sodium fluoride for 28 days and in group V, specimens were subjected to 50,000 cycles of $100 \mathrm{~N}$ axial loading under compression while immersed in artificial saliva containing $1500 \mathrm{ppm}$ sodium fluoride. Surface topography was evaluated using atomic force microscope (AFM), scanning electron microscope (SEM) and chemical changes were assessed using Energy-Dispersive X-ray Spectroscopy (EDX).

Results: AFM results showed increased mean roughness $(\mathrm{Ra})$ of both $\mathrm{CpTi}$ and Ti-6Al-4V alloy after exposure to fluoride as well as combination of mechanical stresses and fluoride. SEM evaluation showed alteration in surface topography of both groups showing deposits, cracks and concavities. EDX analysis for both groups revealed the presence of $\mathrm{Ca}, \mathrm{P}, \mathrm{Na}$ and $\mathrm{F}$ together with $\mathrm{Ti}$ for $\mathrm{CpTi}$ or $\mathrm{Ti}, \mathrm{Al}, \mathrm{V}$ for titanium alloy suggesting the formation of sodium and fluoride complexes with titanium, in addition to $\mathrm{Ca} / \mathrm{P}$ deposits.

Conclusions: Fluoride application as well as combination of mechanical stresses and fluoride application can induce surface chemical and topographical changes which may have an impact on corrosion behavior of CpTi and Ti-6Al-4V alloy.

* Associate Professor, Biomaterials Department, Faculty of Dentistry, Ain-Shams University, Cairo, Egypt. 


\section{INTRODUCTION}

Analysis of the implant surface is necessary to ensure a two-fold requirement. First, the implant materials cannot adversely affect body tissues and organs; second, the in-vivo environment cannot degrade the implant and compromise its long-term function. The interfacial zone between the implant and the surrounding tissue is therefore the most important entity for defining the biological response to the implant and the response of the implant to the body. Surface analysis in implantology therefore aids in material characterization, determining structural and composition changes occurring during processing, identifying biologically induced surface reactions, and analyzing environmental effects on the interfaces. ${ }^{1}$

Commercially pure titanium and titanium aluminum vanadium alloys are widely used in manufacturing dental implants ${ }^{1-4}$ owing to their favorable mechanical properties, good corrosion resistance and acceptable biocompatibility. ${ }^{2-4}$ The biological environment is highly aggressive for metallic implants. ${ }^{5}$ Titanium in the oral cavity is not inert to corrosion when exposed to acids and fluoride. ${ }^{5,6}$ Resistance to corrosion and biocompatibility are directly related to the passive oxide layer formed on titanium's surface and its alloys. ${ }^{7,8}$ However, the mere presence of the oxide layer does not maintain the stability, since its surface may not be fully protected in the very complex chemistry of the oral cavity. This layer may be mechanically or chemically removed or destroyed. ${ }^{7}$

Corrosion products can directly influence adjacent tissues and the formation of a biofilm on supracrevicular or intracrevicular implant restoration surfaces. The metal ions released into the surrounding tissues may induce the release of potentially osteolytic cytokines involved in implant loosening ${ }^{9}$ causing discoloration of the tissues and even more severe problems such as inflammatory reaction of the tissues. ${ }^{10}$ As a result, many publications have dealt with the corrosion resistance of titanium implants under various conditions. ${ }^{11-19}$

Whilst titanium shows high resistance to corrosion in artificial saliva, ${ }^{20,21} 0.9 \% \mathrm{NaCl}^{21}$ and physiological saline solution, ${ }^{21}$ fluoride ions from toothpastes, dental gels and mouth rinses can cause deleterious effects on CpTi and Ti-6Al-4V.,20-28 Alteration in surface topography of titanium surface exposed to fluorides have been reported. ${ }^{3,23,29}$ The fluoride content of commercially fluoridated acidic toothpastes, mouth rinses or cariostatic gels is between $0.1 \%(1000 \mathrm{ppm})$ to $1 \%(10,000 \mathrm{ppm})$ and is most often added as the sodium salt, $\mathrm{NaF} .{ }^{30}$

During service, dental implants are subjected to cyclic loading ${ }^{31}$ which results in microscopically small zones of stress concentration produced by notches or microstructural inhomogeneities. ${ }^{32}$ The material starts to develop internal micro-cracks that may increase in number and size according to the number of cycles. ${ }^{33}$ Fluoride-containing solutions, together with applied stresses may enhance corrosion in prosthetic devices. Since the corrosion of titanium is a complicated phenomenon, the susceptibility of titanium to degradation by any type of corrosion should always be considered in the application environment. ${ }^{34}$

Accordingly, this study has been conducted to investigate the individual effect of fluoride application, mechanical stresses and their combined effect on the surface characteristics and hence the corrosion behavior of $\mathrm{CpTi}$ and $\mathrm{Ti}-6 \mathrm{Al}-4 \mathrm{~V}$. The null hypothesis tested was that mechanical stresses, fluoride application and their combined effect would not affect the surface characteristics and hence the corrosion behavior of $\mathrm{CpTi}$ and Ti-6Al-4V.

\section{MATERIALS AND METHODS}

Commercially pure titanium grade II and titanium-aluminum-vanadium alloy (Modern Techniques center, Cairo-Egypt) were used in this study. The composition of the materials used in the 
study is shown in table 1 . In an attempt to mimic the dimensions of one of the available dental implants, cylindrical specimens $6 \mathrm{~mm}$ in diameter and $8 \mathrm{~mm}$ in length ${ }^{35}$ were machined and their lateral sides were flattened (Star VNC-20 automatic Swiss lathe, Automatics \& Machinery Co. Colorado, USA). The flattened lateral sides of the specimens were wet polished with 600 to 4000 grit silicon carbide papers, washed sequentially with distilled water, alcohol and acetone and ultrasonically cleaned in deionized water.

TABLE (1) The composition of the CpTi and Ti-6Al-4V.

\begin{tabular}{|l|l|}
\hline Material & Composition (wt \%) \\
\hline CpTi grade II & $\begin{array}{l}\text { Ti: base, O: 0.25, N: 0.03, C: 0.1, H: 0.015, } \\
\text { Fe: 0.03 }\end{array}$ \\
\hline Ti-6Al-4V & $\begin{array}{l}\text { Ti: base, O: 0.2, N: 0.05, C: 0.1, H: 0.01, } \\
\text { Fe: 0.4, Al: 5.5-6.75, V: 3.5- 4.5 }\end{array}$ \\
\hline
\end{tabular}

Polished specimens of CpTi and Ti-6Al-4V were randomized into 5 groups according to the applied treatment $(n=5)$; group I included the as-received specimens that was not subjected to any treatment. Group II included specimens that were immersed in artificial saliva for 28 days; in group III, specimens were subjected to 50,000 cycles ${ }^{36,37}$ of $100 \mathrm{~N}$ axial loading under compression while immersed in artificial saliva; group IV included specimens that were immersed in artificial saliva containing 1500 ppm sodium fluoride for 28 days and group $\mathrm{V}$ included specimens that were subjected to 50,000 cycles of $100 \mathrm{~N}$ axial loading under compression while immersed in artificial saliva containing 1500 ppm sodium fluoride.

TABLE (2) The composition of the artificial saliva

\section{Preparation of the solutions}

Fusayama-Meyer's artificial saliva was prepared and used in this study. ${ }^{38,39}$ The composition of this solution, which closely resembles human natural saliva, is shown in table 2 . The $\mathrm{pH}$ was adjusted at 5.8. ${ }^{40}$

The fluoride medium was prepared by dissolving $0.15 \mathrm{gm}$ sodium fluoride in $100 \mathrm{gm}$ of artificial saliva to obtain a solution containing $1500 \mathrm{ppm}$ $\mathrm{NaF}$. Specimens of group II (artificial saliva group) and group IV (fluoride group) were individually immersed under static conditions in the intended solutions at $37^{\circ} \mathrm{C}$ up to 28 days where the solution was refreshed every $24 \mathrm{~h}$ during the incubation period. After immersion, specimens were removed and rinsed with distilled water, followed by drying at room temperature for $24 \mathrm{~h}$ to be ready for surface characterization.

\section{Application of mechanical stresses}

Specimens of groups III (mechanical stresses) and $\mathrm{V}$ (mechanical stresses and fluoride) were individually mounted onto the lower fixed compartment of a computer controlled materials testing machine (Model 3345; Instron Instruments Ltd., USA) with a load cell of $5 \mathrm{kN}$ and data were recorded using computer software (Bluehill Lite; Instron Instruments). Each specimen was subjected to 50,000 cycles axial loading under compression by means of a metallic rod with flat end of $6 \mathrm{~mm}$ diameter which was attached to the upper movable compartment of the machine. The metallic rod used for load application was made from the same material of the specimen tested. Each specimen was immersed in the test solution in a Teflon cup during stress application.

\begin{tabular}{|c|c|c|c|c|c|c|}
\hline Compounds & $\mathbf{N a C l}$ & $\mathbf{K C l}$ & $\mathbf{C a c l}_{2} . \mathbf{2} \mathbf{H}_{2} \mathbf{O}$ & $\mathbf{N a H}_{2} \mathbf{P O}_{\mathbf{4}} . \mathbf{2} \mathbf{H}_{2} \mathbf{O}$ & $\mathbf{N a}_{2} \mathbf{S . 9 H}_{2} \mathbf{O}$ & Urea \\
\hline $\begin{array}{c}\text { Concentration } \\
(\mathrm{g} / \mathrm{l})\end{array}$ & $0.4 \mathrm{~g}$ & $0.4 \mathrm{~g}$ & $0.906 \mathrm{~g}$ & $0.69 \mathrm{~g}$ & $0.005 \mathrm{~g}$ & $1 \mathrm{~g}$ \\
\hline
\end{tabular}


Load profile in the form of a sine wave at a rate of $1 \mathrm{~Hz}$ was applied. The rate was used as equivalent to the average masticatory cycle of $0.8-1.0$ seconds. ${ }^{41-43}$ The load was cycled at first between a specified maximum $(100 \mathrm{~N})$ and small but non-zero minimum $(20 \mathrm{~N})$ load to avoid lateral dislocation of the loading tip and help in stabilizing the specimen during testing.

\section{AFM evaluation}

Specimens of each group were collected and rinsed three times in deionized water. The AFM (Autoprobe, CP Research-Thermo-Microscopes; Sunnyvale, CA, USA) was used in the contact mode using nonconductive silicon nitride probe (MLCT-MT-A, Bruker AFM probes, Bruker Co., USA) and a scan rate of $1 \mathrm{~Hz}$. Surface examination of the flattened lateral surfaces of the specimens was performed and imaged for an area of $20 \mu \mathrm{m}$ $\mathrm{X} 20 \mu \mathrm{m}$. Roughness average (Ra) measurement was determined by taking the mean value of three individual measures on each of the investigated specimens. The collected 3D data were analyzed using proscan 1.8 software for controlling the scan parameters and IP 2.1 software for image analysis.

\section{SEM evaluation and EDX analysis}

The flattened lateral surfaces of the treated specimens were examined using SEM at 10000X magnification and the chemical analysis of the examined surfaces was further analyzed by EDX spectroscopy. This was performed using Scanning Electron Microscope model Quanta 250 FEG (Field Emission Gun) attached with EDX Unit (Energy Dispersive X-ray Analyses), with accelerating voltage $30 \mathrm{~K} . \mathrm{V}$ (FEI company, Netherlands).

\section{Statistical analysis}

SPSS version 20.0 was used for statistical analysis of the data. Two-way ANOVA was used to compare the effect of material and treatment and their interaction on surface roughness. One-way ANOVA was applied followed by Tukey Kramer post hoc test for pairwise multiple comparisons. The significance level was set at $\mathrm{P}<0.05$.

\section{RESULTS}

The results of this study are shown in tables $3 \& 4$ and figures 1-5. Statistical analysis of surface roughness measurements for the different experimental groups using two-way ANOVA (table 3) revealed significant effect for the material, treatment and their interaction on surface roughness.

Regarding the effect of treatment for $\mathrm{CpTi}$, statistical analysis showed insignificant difference for the as-received, saliva and mechanical stresses groups. There was also insignificant difference between fluoride group and combined mechanical stresses and fluoride group, where both groups were statistically higher than all other experimental

TABLE (3) Two way ANOVA for the effect of material, treatment and their interaction on surface roughness

\begin{tabular}{|l|c|c|c|c|c|}
\hline Source & Type III Sum of Squares & Df & Mean Square & F & Sig. \\
\hline Material & 243.278 & 1 & 243.278 & 42.410 & .000 \\
Treatment & 7001.796 & 4 & 1750.449 & 305.148 & .000 \\
Material*Treatment & 85.219 & 4 & 21.305 & 3.714 & .012 \\
Error & 229.456 & 40 & 5.736 & & \\
Total & 77013.139 & 50 & & & \\
Corrected Total & 7559.748 & 49 & & & \\
\hline
\end{tabular}


groups. For Ti-6Al-4V, combined mechanical stresses and fluoride group revealed the highest significant mean roughness followed by fluoride group with significant difference between the two groups. Both groups were significantly higher than the other experimental groups. There were insignificant difference in mean surface roughness values of the as-received, saliva and mechanical stresses groups. Statistical analysis for the effect of material showed insignificant difference in surface roughness between $\mathrm{CpTi}$ and $\mathrm{Ti}-6 \mathrm{Al}-4 \mathrm{~V}$ for the asreceived, saliva and mechanical stresses groups. On the other hand, Ti-6Al-4V showed significantly higher surface roughness for the fluoride group and the combined mechanical stresses and fluoride group (table 4).

TABLE (4) Means, standard deviation values (SD) and significance of surface roughness (nm) of the different groups for $\mathrm{CpTi}$ and Ti-6Al-4V alloy

\begin{tabular}{|c|c|c|c|c|c|c|}
\hline & $\begin{array}{l}\text { AS received } \\
\text { Group }\end{array}$ & $\begin{array}{l}\text { Saliva } \\
\text { group }\end{array}$ & $\begin{array}{c}\text { Mechanical stresses } \\
\text { group }\end{array}$ & $\begin{array}{l}\text { Fluoride } \\
\text { group }\end{array}$ & $\begin{array}{c}\text { Mechanical } \\
\text { stresses and } \\
\text { fluoride group }\end{array}$ & Significance \\
\hline CpTi & $\begin{array}{c}23.98 \\
(2.85) \\
\mathrm{Ba}\end{array}$ & $\begin{array}{c}25.35 \\
(3.21) \\
\mathrm{Ba}\end{array}$ & $\begin{array}{c}30.58 \\
(3.78) \\
\mathrm{Ba}\end{array}$ & $\begin{array}{c}45.62 \\
(4.46) \\
\mathrm{Ab}\end{array}$ & $\begin{array}{c}50.16 \\
(4.3) \\
\mathrm{Ab}\end{array}$ & $\mathrm{P}<0.0001$ \\
\hline Ti-6Al-4V & $\begin{array}{c}26.75 \\
(1.61) \\
\mathrm{Ca}\end{array}$ & $\begin{array}{c}29.89 \\
(3.96) \\
\mathrm{Ca}\end{array}$ & $\begin{array}{c}31.23 \\
(2.34) \\
\mathrm{Ca}\end{array}$ & $\begin{array}{c}51.79 \\
(3.59) \\
\mathrm{Ba}\end{array}$ & $\begin{array}{c}58.46 \\
(4.12) \\
\text { Aa }\end{array}$ & $\mathrm{P}<0.0001$ \\
\hline Significance & $\mathrm{P}=0.095$ & $\mathrm{P}=0.0816$ & $\mathrm{P}=0.752$ & $\mathrm{P}=0.0425$ & $\mathrm{P}=0.0143$ & \\
\hline
\end{tabular}

Groups with different upper case letters indicates significance between different groups within the same materials (among rows).

Groups with different lower case letters indicates significance between different materials within the same treatment modalitiy (among columns).

\begin{tabular}{|l|c|c|}
\hline CPTi & Ti-6Al-4V \\
\hline AS received & & \\
\hline
\end{tabular}




\begin{tabular}{|c|c|c|}
\hline $\begin{array}{l}\text { Group immersed } \\
\text { in artificial saliva }\end{array}$ & unddiv & $\mathrm{D}$ \\
\hline $\begin{array}{l}\text { Group subjected to } \\
\text { mechanical stresses } \\
\text { while immersed in } \\
\text { artificial saliva }\end{array}$ & 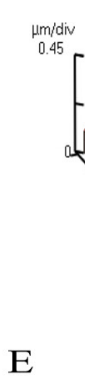 & $\mathrm{F}$ \\
\hline $\begin{array}{l}\text { Group immersed } \\
\text { in sodium fluoride } \\
\text { solution }\end{array}$ & $\int_{0.42}^{u+4 h / d i v}$ & ${ }_{0.19}^{u n d d v}$ \\
\hline $\begin{array}{l}\text { Group subjected to } \\
\text { mechanical stresses } \\
\text { and fluoride }\end{array}$ & $\begin{array}{l}\mu m / 1 \\
0.1\end{array}$ & $\mu_{0.16}$ \\
\hline
\end{tabular}

Fig. 1 (A-J): AFM images of CpTi and Ti-6Al-4V for the different treatment modalities. 


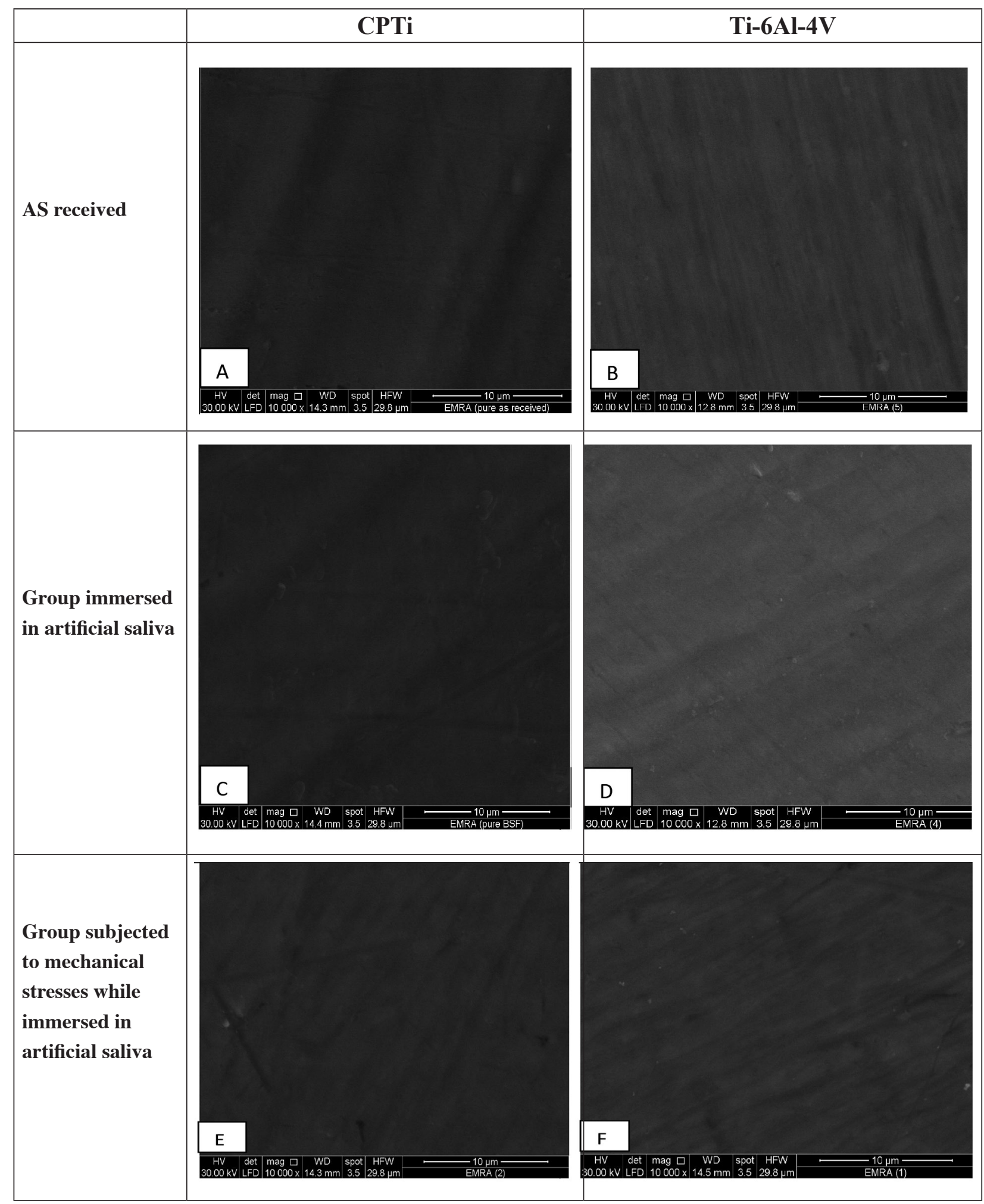




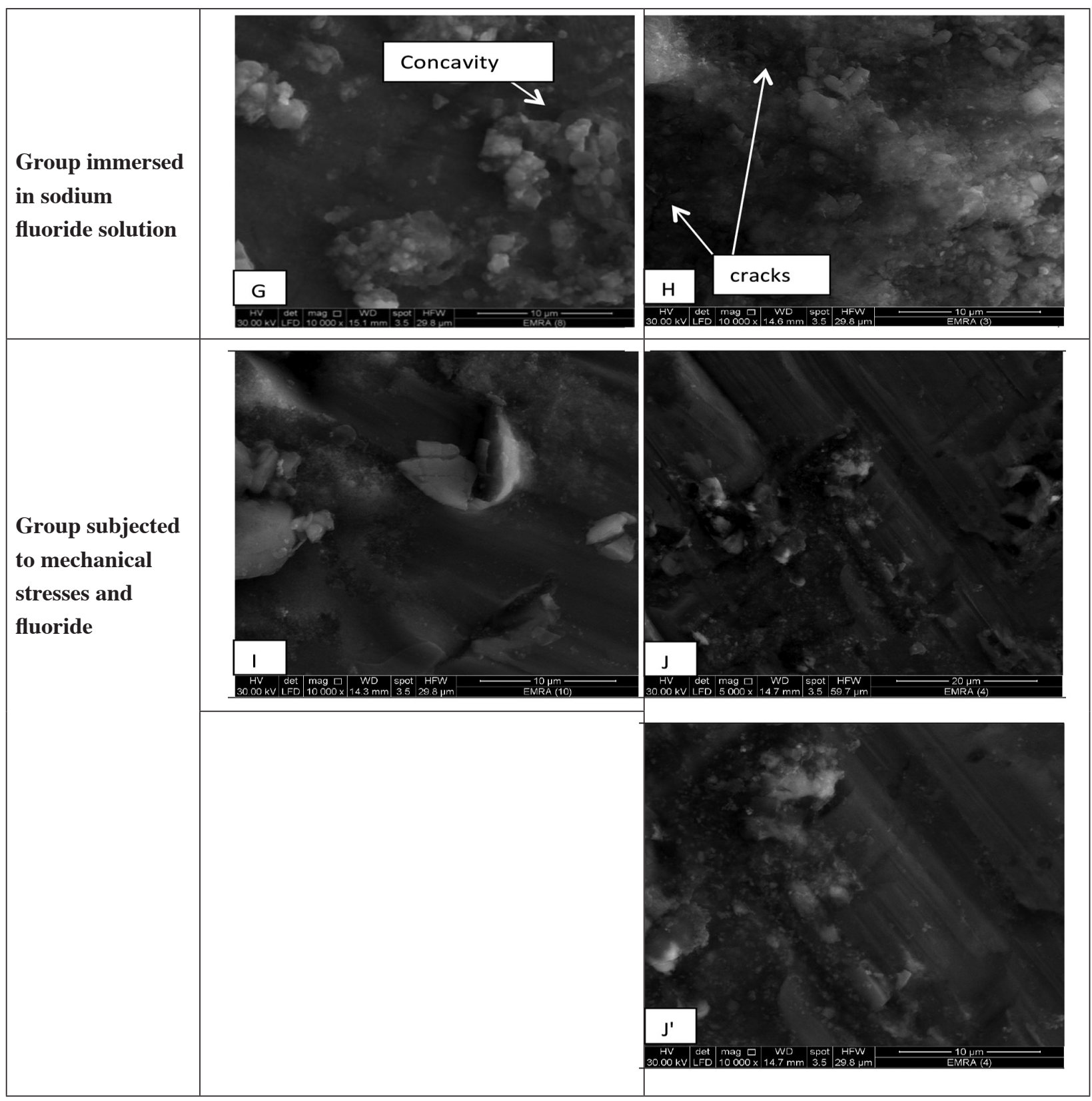

Fig 2 (A-J'): SEM photomicrographs of CpTi and Ti-6Al-4V for the different treatment modalities.

AFM and SEM findings for surface topography of the as received, saliva and mechanically stressed groups of CpTi and Ti-6Al-4V revealed relatively smooth surfaces with homogenous surface texture except for finishing and grinding scratches (fig 1A-F, 2A-F). AFM images showed highly irregular surfaces for the fluoride group and those subjected to combined mechanical stresses and fluoride compared to the as received, saliva, and mechanical stresses groups for both CpTi and Ti-6Al-4V (fig 1).

SEM images of Ti-6Al-4V immersed in artificial saliva and those subjected to mechanical stresses while immersed in saliva (fig 2D, F) revealed few deposits of $\mathrm{Ca} / \mathrm{P}$ as identified by $\mathrm{EDX}$ 
(fig3 representative of alloy immersed in artificial saliva). SEM photomicrograph of specimens immersed in $0.1 \% \mathrm{NaF}$ solution for 28 days showed precipitation of surface crystalline deposits on CpTi (fig 2G) and denser, less regular cloudy deposits together with the crystalline deposits on Ti-6Al-4V surface (fig 2H). They were identified by EDX analysis as $\mathrm{Ca}, \mathrm{P}, \mathrm{Na}$ and $\mathrm{F}$ together with $\mathrm{Ti}$ for $\mathrm{CpTi}$ or Ti, $\mathrm{Al}, \mathrm{V}$ for titanium alloy. The ratio Na: Ti: $\mathrm{F}=24: 11$ : 65 in atomic \% suggested the formation of sodium and fluoride complexes with titanium together with $\mathrm{Ca} / \mathrm{P}$ deposits (figs $4 \& 5$ ). In CpTi and Ti-6Al$4 \mathrm{~V}$, SEM images for specimens subjected to the combined action of mechanical stresses and fluoride revealed partial removal of the surface deposits leaving discrete isolated areas together with surface grooves, concavities and pits (fig 2I for $\mathrm{CpTi}$ and $2 \mathrm{~J}$, J' for Ti-6Al-4V).

\section{DISCUSSION}

Degree of success of an implant is determined by the interaction between the implant and the surrounding environment at their interface. ${ }^{44}$ Titanium is known to present a high degree of resistance against corrosion attacks by the majority of acids. The corrosion resistance of titanium and its alloys is a result of the material's ability to spontaneously form passive oxide films (TiO2) when in contact with oxygen.$^{45}$ Titanium oxide is a stable and dense layer, which acts as a protective barrier to continued metallic oxidation. In the event of damage, $\mathrm{TiO} 2$ has the ability to spontaneously reform under normal physiological conditions. However, events, such as loading conditions, implant micromotion, acidic environments and their conjoint effects, can result in permanent breakdown of the oxide film, which may consequently lead to exposure of the bulk metal to an electrolyte. ${ }^{46}$

Fluoride ions are considered to be one of the few means capable of attacking titanium surface with corrosive action. The use of fluoridated gels and mouth washes as a prophylactic measure in

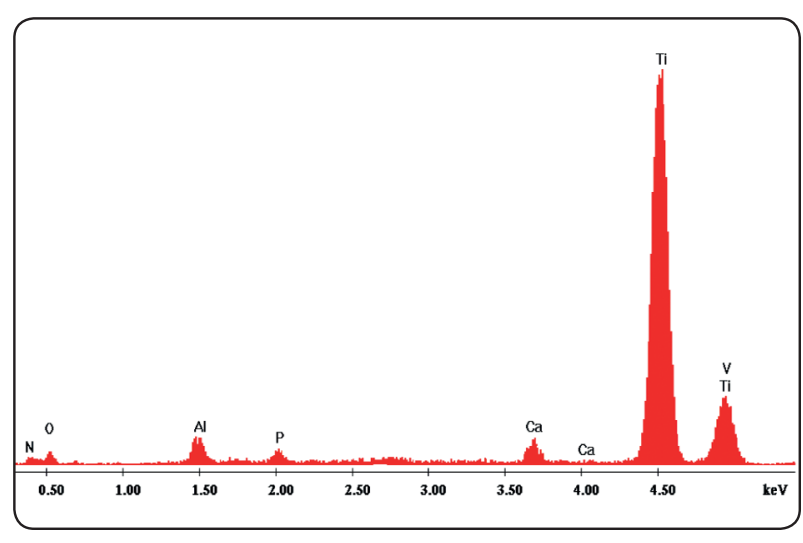

Fig. (3) EDX analysis of Ti-6Al-4V in artificial saliva.

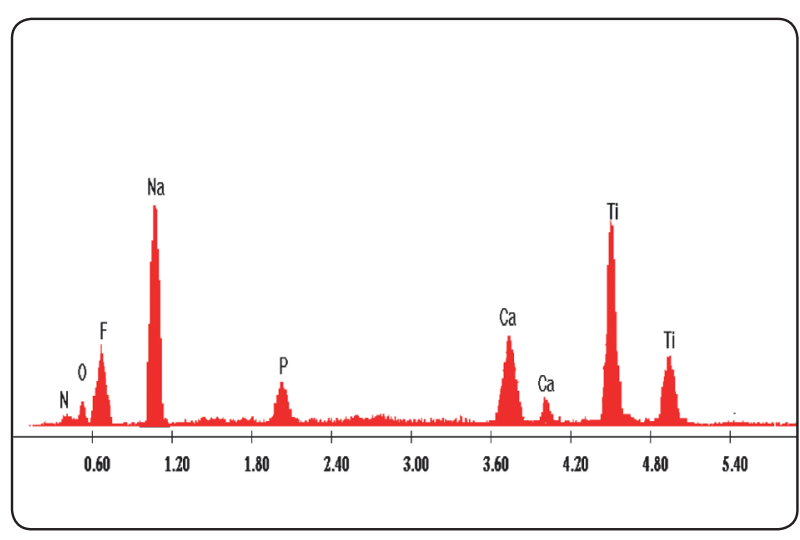

Fig. (4) EDX analysis of CpTi immersed in sodium fluoride.

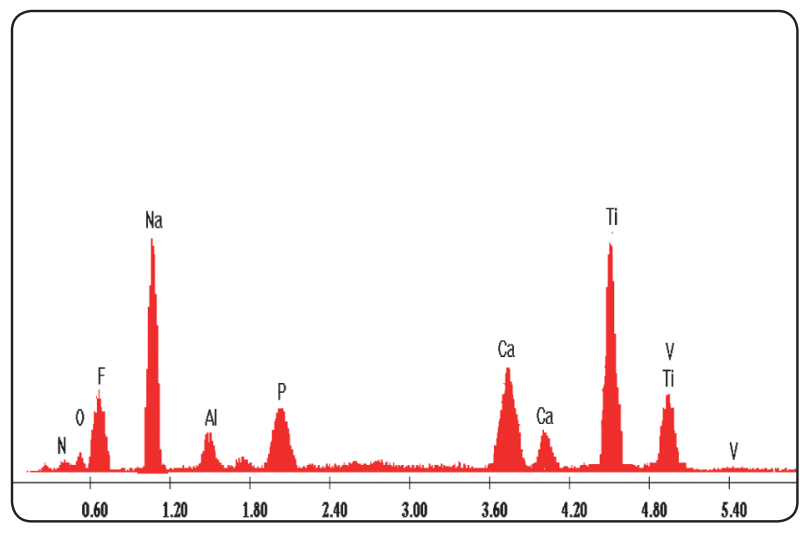

Fig (5) EDX analysis of Ti-6Al-4V immersed in sodium fluoride solution. 
dentistry has been increasingly more widespread over the last 40 years, due to the great impact on caries prevention. ${ }^{47}$ In this study, the concentration of fluoride used was within the range observed in tooth pastes reported in clinical studies ${ }^{48}$ and used in dental implant research studies. ${ }^{5,33}$ Similarly, Fusayama-Meyer solution was selected because it is common in dental implant ${ }^{49,15}$ and orthodontic ${ }^{50,51}$ corrosion studies. Electrolytes of the Fusayamatype have been regarded to closely resemble natural saliva when testing the electrochemical behavior of dental alloys and yield results that match clinical observations. ${ }^{52,53}$ The $\mathrm{pH}$ was adjusted to 5.8 where the normal $\mathrm{pH}$ range for saliva is considered to be 5.6-7.9 ${ }^{54}$ with children having an average $\mathrm{pH}$ of 7.5 while adults tend to be more acidic. Still, the characteristics of the oral environment are complex and difficult to replicate in any artificial saliva and in in-vitro studies in general.

The presence of mechanical stimulus and the synergistic effect of mechanical loading during fluoride immersion were also investigated in this study. During mechanical testing, the teeth were subjected to an axial loading of $100 \mathrm{~N}$, which is considered to be within the normal functional range in-vivo (70 to $150 \mathrm{~N}$ ) during chewing and swallowing. ${ }^{55-57}$ For cyclic loading testing, axial load with constant amplitude was applied as a first step towards more complex testing conditions. The lateral sides of the specimens were examined to avoid possible damaging effects of the load applicator on the top surfaces.

The significant increase in roughness for the fluoride group compared to the as-received, saliva and mechanical stresses groups could be attributed to alteration in surface topography as a result of the formed surface deposits, concavities and cracks. When sodium fluoride agents come in contact with titanium, sodium and fluoride ions are released. Fluoride ions combine with hydrogen generating hydrofluoric acid (HF), which reacts with the oxide layer, dissolving titanium. The reaction with the oxide layer may contribute to the formation of titanium fluoride, titanium oxide fluoride or sodium titanium fluoride on the surface. ${ }^{22,24,3,58,59}$ In addition, $\mathrm{Ca} / \mathrm{P}$ deposits from solution have also been detected. ${ }^{3}$

Some controversy exists regarding whether exposure to fluoride is detrimental to titanium if the $\mathrm{pH}$ is closer to neutral. ${ }^{60,61}$ According to Nakagawa et al. ${ }^{21,27,62}$ titanium changes induced by fluoride can be predicted by $\mathrm{pH}$ and fluoride concentration. Considering this predictive model, for a fluoride concentration of $1500 \mathrm{ppm}$, corrosion should only occur if $\mathrm{pH}$ is lower than 4.7 for $\mathrm{CpTi}$ and 5.1 for Ti-6Al-4V. Accordingly, at least 10,000 ppm F seem to be necessary in order to corrode titanium when toothpastes with $\mathrm{pH}$ equal to 6.3 are used. Reclaru and Meyer ${ }^{63}$ found deposition of fluoride when titanium was immersed in a 1000 ppm F solution at a $\mathrm{pH}=3.5$. Sartori et al. ${ }^{64} \mathrm{did}$ not found fluoride ions or crystals on the surface of implants after immersion in NaF solution (1500 ppm F and $\mathrm{pH}$ ranging from 5.3 to 7.4). Though the $\mathrm{pH}$ of the artificial saliva in this study was 5.8 and only decreased to 5.6 with the addition of $\mathrm{NaF}$, yet this was sufficient to affect the titanium surface particularly with the prolonged immersion period applied compared to the other studies, supporting Yokoyama et al ${ }^{61}$ and Knutson and Berzins ${ }^{40}$ where they showed that fluoride at more neutral $\mathrm{pH}(\mathrm{pH}=$ 6.5) may also have an influencing effect on titanium. In addition, Schutz and Thomas ${ }^{65}$ reported that solutions containing more than $20 \mathrm{ppm}$ of fluoride ions may attack titanium surfaces when the $\mathrm{pH}$ falls below 6.0. Thus, it could be speculated that titanium changes induced by fluoride can be affected not only by $\mathrm{pH}$ and fluoride concentration but also by time of immersion.

Even though the application of mechanical stresses did not significantly alter surface roughness, the combined effect of mechanical stresses and 
fluoride application revealed a significant increase in surface roughness compared to the as-received, saliva and mechanical stresses groups for CpTi and showed the highest surface roughness values for Ti-6Al-4V groups. It has been reported ${ }^{66}$ that the formation of oxide film in titanium provides corrosion resistance under static conditions, but the oxide film may not be sufficiently stable under different loading conditions. It has been shown that fluoride prophylactic agents attack the titanium surface creating surface pits, microcracks and grooves which can modify titanium performance under cyclic stresses..$^{28,60}$ As a consequence, mechanical stresses with even normal physiological load are concentrated in these surface defects ${ }^{67}$ and act as crack nucleation sites. ${ }^{68}$ In addition, in corrosive environment like fluoride solution, crack propagation is relatively rapid in stressed specimens. ${ }^{68,69}$

Thus, it can be assumed that the combined mechanical and chemical processes play a vital role in crack initiation and propagation. According to previous studies, the formation of titanium fluoride, titanium oxide fluoride or sodium titanium fluoride on titanium surface results in marked decrease in corrosion resistance. ${ }^{3,22,24,58,59}$ However, accumulation of such deposits on the surface of CpTi and Ti-6Al-4V induced by the initial corrosion attack, together with the $\mathrm{Ca} / \mathrm{P}$ deposited from the solution might provide a protective barrier for the so called active metal and decrease the susceptibility for further corrosion..$^{70-72}$ Unfortunately, the mechanical action would lead to partial removal of the layer of deposits formed on titanium surface (as revealed by SEM fig 2I,J,J'), eliminating the protective function of the layer, which leads to continuous exposure of the metal and hence promoting its degradation.

$\mathrm{Ca} / \mathrm{P}$ deposits were detected in fluoride groups of $\mathrm{CpTi}$ and $\mathrm{Ti}-6 \mathrm{Al}-4 \mathrm{~V}$ and sparse deposits were also seen on Ti-6Al-4V immersed in saliva and specimens subjected to mechanical stresses while immersed in saliva. This could be explained based on the bioactivation effect of fluoride in $\mathrm{Ca}$ and $\mathrm{P}$ containing solutions, where fluoridation increased the nucleation rate and accelerates the deposition of calcium phosphate..$^{73,74}$

Regarding the effect of material, there was no significant difference in surface roughness between CpTi and Ti-6Al-4V for the as-received, saliva and mechanical stresses groups. On the other hand, Ti6Al-4V showed significantly high surface roughness for the fluoride group and the combined mechanical stresses and fluoride group. This indicates that Ti-6Al-4V is more susceptible to corrosion in fluoride media compared to $\mathrm{CpTi}$ which could be attributed to the presence of $\mathrm{Al}$ and $\mathrm{V}$ causing the formation of a more defective surface oxide film. In fact, $\mathrm{Al}$ and $\mathrm{V}$ improve the alloy strength ${ }^{65}$ but, on the other hand, they increase the anodic dissolution of the alloy. ${ }^{75}$ Literature data have revealed the release of Al- and V-ions caused by passive film dissolution, though those alloying elements confer good mechanical properties to Ti-alloys. ${ }^{76}$

Based on the results obtained in this study, the null hypothesis was rejected as mechanical stresses, fluoride application and the synergistic effect of mechanical stresses and fluoride application affected surface roughness and topography of titanium based materials which may render them more prone to corrosion and surface degradation. Considering the fact that most implant patients use prophylactic fluoride-containing gels, dentifrices or supplementary fluoride, it is possible that fluoride ions may contribute to degradation of the accessible sites at implant surfaces. Finally, it is important to highlight that prolonged contact of titanium implants either CpTi or Ti-6Al-4V with even relatively low concentration of fluoride ions (1500 ppm) are considered harmful to the implant durability. Accordingly, even in cases where fluoride treatment is highly recommended, it should not be used on routine daily basis. 


\section{CONCLUSIONS}

Within the limitations of this study, the following could be concluded:

1. Mechanical stresses, fluoride application and the combined effect of fluoride application and mechanical stresses altered the surface topography of titanium and titanium alloy.

2. The synergistic effect of mechanical stresses and fluoride application render titanium more prone to corrosion and surface degradation.

3. Ti-6Al-4V is more susceptible to corrosion attacks in fluoride media compared to CpTi.

\section{REFERENCES}

1- Sakaguchi RL, Powers JM. Dental and orofacial implants. In: Craig's restorative dental materials. $13^{\text {th }}$ ed. Elsevier Mosby, Philadelphia 2012: 231, 232,361.

2- de Assis SL, Wolynec S, Costa I. Corrosion characterization of titanium alloys by electrochemical techniques. Electrochimica Acta 2006;51:1815-1819.

3- Mabilleau G, Bourdon S, Joly-Guillou ML, Filmon R, Basle MF, Chappard D. Influence of fluoride, hydrogen peroxide and lactic acid on the corrosion resistance of commercially pure titanium. Acta Biomaterialia 2006;2:121-129.

4- Souza ME, Lima L, Lima CR, Zavaglia CA, Freire CM. Effects of $\mathrm{pH}$ on the electrochemical behaviour of titanium alloys for implant applications. Journal of Materials Science: Materials in Medicine 2009;20:549-552.

5- Correa CB, Pires JR, Fernandes-Filho RB, Sartori R, Vaz LG. Fatigue and fluoride corrosion on Streptococcus mutans adherence to titanium-based implant/component surfaces. Journal of Prosthodontics 2009;18:382-387.

6- Joska L, Fojt J. Corrosion behaviour of titanium after short-term exposure to an acidic environment containing fluoride ions. Journal of Materials Science: Materials in Medicine 2010;21:481-488.

7- Sivakumar B, Kumar S, Narayanan TSNS. Fretting corrosion behavior of Ti-6Al-4V alloy in artificial saliva containing varying concentrations of fluoride ions. Wear 2010;270:317-324.

8- Hanawa T, Asami K, Asaoka K. Repassivation of titanium and surface oxide film regenerated in simulated bioliquid. Journal of Biomedical Materials Research 1998; 40:530-538.

9- Rogers SD, Howie DW, Graves SE, Pearcy MJ, Haynes DR. In vitro human monocyte response to wear particles of titanium alloy containing vanadium or niobium. The Journal of Bone and Joint Surgery. British volume 1997;79:311-315.

10- Contu F, Elsener B, Hohni H. Characterization of implant materials in fetal bovine serum and sodium sulfate by electrochemical impedance spectroscopy. I. Mechanically polished samples. Journal of Biomedical Materials Research 2002;62:412-421.

11- Gonzalez JEG, Mirza-Rosca JC. Study of the corrosion behavior of titanium and some of its alloys for biomedical and dental implant applications. Journal of Electroanalytical Chemistry 1999;471: 109-115.

12- Krupa D, Baszkiewicz J, Sobczak JW, Bilinski A, Barcz A. Modifying the properties of titanium surface with the aim of improving its bioactivity and corrosion resistance. The Journal of Materials Processing Technology 2003;143:158-163.

13- Cai Z, Nakajima H, Woldu M, Berglund A, Bergman $\mathrm{M}$, Okabe T. In vitro corrosion resistance of titanium made using different fabrication methods. Biomaterials 1999;20:183-190.

14- Cai Z, Shafer T, Watanabe I, Nunn ME, Okabe T. Electrochemical characterization of cast titanium alloys. Biomaterials 2003;24:213-218.

15- Grosgogeat B, Reclaru L, Lissac M, Dalard F. Measurement and evaluation of galvanic corrosion between titanium/ Ti6Al4V implants and dental alloys by electrochemical techniques and auger spectrometry. Biomaterials 1999;20:933-941.

16- Hanawa T, Hiromoto S, Asami K, Okuno O, Asaoka K. Surface oxide films on titanium alloys regenerated in Hanks' solution. Materials Transactions 2002; 43:3000 3004 .

17- Khan MA, Williams RL, Williams DF. In-vitro corrosion and wear of titanium alloys in the biological environment. Biomaterials 1996;17:2117-2126.

18- Ng BS, Annergren I, Soutar AM, Khor K A, Jarfors AEW. Characterization of a duplex $\mathrm{TiO} 2 / \mathrm{CaP}$ coating on Ti6Al4V for hard tissue replacement. Biomaterials 2005; 26:1087-1095. 
19- Okazaki Y, TateishiT,Ito Y. Corrosion resistance of implant alloys in pseudo physiological solution and role of alloyingelements in passive films. Mater Trans,JIM 1997;38:78-84.

20- Al-Mayouf AM, Al-Sawayih AA, Al-Mobarak NA, AlJabab AS. Corrosion behavior of a new titanium alloy for dental implant application in fluoride media. Materials Chemistry and Physics 2004;86:320-329.

21- Nakagawa M, Matsuya S, Shiraishi T, Ohta M. Effect of fluoride concentration and $\mathrm{pH}$ on corrosion behavior of titanium for dental use. Journal of Dental Research 1999; 78:1568-1572.

22- Stajer A, Ungvari K, Pelsoczi IK, Polyanka H, Oszko A, Mihalik E, Rakonczay Z, Radnai M, Kemény L, Fazekas A, Turzó K. Corrosive effects of fluoride on titanium: investigation by $\mathrm{X}$-ray photoelectron spectroscopy, atomic force microscopy,and human epithelial cell culturing. Journal of Biomedical Materials Research Part A 2008; $87: 450458$.

23- Huang HH. Variation in surface topography of different NiTi orthodontic arch wires in various commercial fluoride containing environments. Dental Materials 2007;23:24-33.

24- Matono Y, Nakagawa M, Matsuya S, Ishikawa K, Terada Y. Corrosion behavior of pure titanium and titanium alloys in various concentrations of Acidulated Phosphate Fluoride (APF) solutions. Dental Materials Journal 2006; 25:104-112.

25- Kononen MH, Lavonius ET, Kivilahti JK. SEM observations on stress corrosion cracking of commercially pure titanium in a topical fluoride solution. Dental Materials 1995; 11: 269-272.

26- Popa MV, Vasilescu E, Drob P, Vasilescu C, Demetrescu I, Ionita D. Long-term assessment of the implant titanium material-artificial saliva interface. Journal of Materials Science Materials in Medicine 2008;19:1-9.

27-Nakagawa M, Matsuya S, Udoh K. Corrosion behavior of pure titanium and titanium alloys in fluoride-containing solutions. Dental Materials Journal 2001;20:305-314.

28- Siirila HS, Kononen M. The effect of oral topical fluorides on the surface of commercially pure titanium. International Journal of Oral \& Maxillofacial Implants 1991;6:50-54.

29- Stajer A, Radnai M, Pelsoczi KI, Turzo K, Oszko A, Fazekas A. The effect of fluorides on the surface structure of titanium implants. Fogorvosi Szemle 2006;99:53-59.
30- Shim HM, Oh KT, Woo JY, Hwang CJ, Kim KN. Corrosion resistance of titanium-silver alloys in an artificial saliva containing fluoride ions. Journal of Biomedical Materials Research: Part B, Applied Biomaterials 2005;73:252-259.

31- Tavarez RR DJ, Bonachela WC, Xible AA. Effect of cyclic load on vertical misfit of prefabricated and cast implant single abutment. Journal of Applied Oral Science. 2011;19:16-21.

32- Long M, Rack H. Titanium alloys in total joint replacement-a materials science perspective. Biomaterials 1999; 19:1621-1639.

33- Ribeiro ALR, Noriega JR, Dametto FR, Vaz LG. Compressive fatigue in titanium dental implants submitted to fluoride ions action. Journal of Applied Oral Science 2007;15:299-304.

34- Myers JR, Bomberger HB, Froes FH. Corrosion behavior and use of titanium and its alloys. Journal of Metals 1984;36: 50-60.

35- Griffin TJ, Cheung WS. The use of short, wide implants in posterior areas with reduced bone height: a retrospective investigation. Journal of Prosthetic Dentistry 2004;92: 139-144.

36- Freitas AC Jr , Bonfante EA, Rocha EP, Silva NR, Marotta L, Coelho PG. Effect of implant connection and restoration design (screwed vs. cemented) in reliability and failure modes of anterior crowns. European Journal of Oral Sciences. 2011;119:323-330.

37- Almeida EO, Freitas AC Jr,. Bonfante EA, Marotta L, Silva NR, Coelho PG. Mechanical Testing of ImplantSupported Anterior Crowns with Different Implant/ Abutment Connections. The International Journal of Oral \& Maxillofacial Implants 2013;28:103-108.

38- Kinani L, Chtaini A. Corrosion inhibition of titanium in artificial saliva containing fluoride. Leonardo Journal of Sciences 2007;11: 33-40.

39-Rajendran S, Paulraj J, Rengan P, Jeyasundari J, Manivannan M. Corrosion behaviour of metals in artificial saliva in presence of spirulina powder. Journal of Dentistry and Oral Hygiene 2009;1:001-008.

40- Knutson KJ, Berzins DW. Corrosion of orthodontic temporary anchorage devices. European Journal of Orthodontics 2013; 35: 500-506.

41- Li H, Burrow M F, Tyas M J. The effect of load cycling on the nanoleakage of dentin bonding systems. Dental Materials 2002;18: 111-119. 
42- Abo El Naga A, Yousef M, Ramadan R, Bahgat SF, Alshawwa L. Does the use of a novel self-adhesive flowable composite reduce nanoleakage? Clinical, Cosmetic and Investigational Dentistry 2015;7:55-64.

43- Abo El Naga A. Nanoleakage of giomer resin bonded with either total- or self-etch adhesives. Journal of American Science 2012;8:27-34.

44- Kamachimudali U, Sridhar TM, Raj B. Corrosion of bio implants. Sadhana (Academy proceedings in engineering sciences) 2003; 28:601-637.

45- Long M, Rack HJ. Titanium alloys in total hip replacement-A materials science perspective: Review. Biomaterials 1998;19:1621-1639.

46- Rodrigues DC, Valderrama P, Wilson TG, Jr., Palmer K, Thomas A, Sridhar S, Adapalli A, Burbano M, Wadhwani C. Titanium Corrosion Mechanisms in the Oral Environment: A Retrieval Study. Materials 2013; 6: 5258-5274

47- Stookey GK. Critical evaluation of the composition and use of topical fluorides. Journal of Dental Research1990;69:805-812.

48- Twetman S, Axelsson S, Dahlgren H, Holm AK, Källestål C, Lagerlöf F, Lingström P, Mejàre I, Nordenram G, Norlund A, Petersson LG, Söder B. Caries-preventive effect of fluoride toothpaste: a systematic review. Acta Odontologica Scandinavica 2003;61:347-355.

49- Reclaru L, Meyer JM. Study of corrosion between a titanium implant and dental alloys. Journal of Dentistry 1994;22:159-168.

50- Schiff N, Grosgogeat B, Lissac M, Dalard F. Influence of fluoridated mouthwashes on corrosion resistance of orthodontics wires. Biomaterials 2004; 25: 4535-4542.

51- Schiff N, Dalard F, Lissac M, Morgon L, Grosgogeat B. Corrosion resistance of three orthodontic brackets: a comparative study of three fluoride mouthwashes. European Journal of Orthodontics 2005; 27: 541-549.

52- Holland RI. Corrosion testing by potentiodynamic polarization in various electrolytes. Dental Materials 1992; 8:241-245.

53- Ayad MF, Vermilyea SG, Rosenstiel SF. Corrosion behavior of as-received and previously cast high noble alloy. Journal of Prosthetic Dentistry 2008; 100: 34-40.

54- Kidwell DA, Holland JC, Athanaselis S. Testing for drugs of abuse in saliva and sweat. Journal of Chromatography B 1998, 713: 111-135.
55- Jang KT, Chung DH, Shin D, Garcia-Godoy F. Effect of eccentric load cycling on microleakage of Class V flowable and packable composite resin. Journal of Operative Dentistry 2001;26:603-608.

56- Li H, Burrow MF, Tyas MJ. The effect of load cycling on the nanoleakage of dentin bonding systems. Dental Materials 2002;18:111-119.

57- González-López S, De Haro-Gasquet F, Vílchez-Díaz MÁ, Ceballos L, Bravo M. Effect of restorative procedures and occlusal loading on cuspal deflection. Journal of Operative Dentistry 2006;31:33-38.

58- Kaneko K, Yokoyama K, Moriyama K, Asaoka K, Sakai J, Nagumo M. Delayed fracture of beta titanium orthodontic wire in fluoride aqueous solutions. Biomaterials 2003;24:2113-2120.

59- Huang HH. Effects of fluoride concentration and elastic tensile strain on the corrosion resistance of commercially pure titanium. Biomaterials 2002;23:59-63.

60- Probster L, Lin W, Hutteman H. Effect of Fluoride prophylactic agents on titanium surfaces. International Journal of Oral and Maxillofacial Implants 1992; 7:390-394.

61- Yokoyama K, Kaneko K, Miyamoto Y, Asaoka K, Sakai J, Nagumo M. Fracture associated with hydrogen absorption of sustained tensile loaded titanium in acid and neutral fluoride solutions. Journal of Biomedical Materials Research Part A 2004; 68: 150-158.

62- Nakagawa M, Matsuya S, Udoh K. Effects of fluoride and dissolved oxygen concentrations on the corrosion behavior of pure titanium and titanium alloys. Dental Materials Journal 2002;21:83-92.

63- Reclaru L, Meyer JM. Effects of fluorides on titanium and other dental alloys in dentistry. Biomaterials 1998; 19:85-92.

64- Sartori R, Correa CB, Marcantonio E Jr, Vaz LG. Influence of a fluoridated medium with different $\mathrm{pHs}$ on commercially pure titanium-based implants. Journal of Prosthodontics 2009; 18:130-134.

65- Schutz RW, Thomas DE. Corrosion of titanium and its alloys. In: ASM International. Metals Handbook.19 ${ }^{\text {th }}$ ed. Ohio, USA: ASM International; 1987;13: 669-706.

66- Lucas LC, Lemons JE. Biodegradation of restorative metallic systems. Advances in Dental Research 1992; 6:32-37. 
67- Leinenbach C, Schwilling B, Eifler D. Cyclic deformation behaviour and fatigue induced surface damage of titanium alloys in simulated physiological media. Materials Science and Engineering 2005;25:321-329.

68- Callister WD, Rethwisch DG. Failure. In: Materials Science and Engineering- An Introduction. $8^{\text {th }}$ ed. John Wiley \&Sons Inc, USA. 2010:260-265.

69- Vallittu PK, Kokkonen M. Deflection fatigue of cobaltchromium, titanium and gold alloy cast denture clasp. Journal of Prosthetic Dentistry 1995;74:412-419.

70- Landolt D, Mischeler S, Stemp M, Barril S. Third body effects and material fluxes in tribocorrosion systems involving a sliding contact. Wear 2004;256:517-524.

71- Ponthiaux P, Wenger F, Drees D, Celis JP. Electrochemical techniques for studying tribocorrosion processes. Wear 2004;256:459-468.

72- Berradja A, Bratu F, Benea L, Willems G, Celis JP. Effect of sliding wear on tribocorrosionbehaviour of stainless steels in a Ringer's solution. Wear 2006; 261:987-993.

73- Cheng K., Weng W, Qu H, Du P, Shen G, Han G, Yang J, Ferreira J. Sol-gel preparation and in vitro test of fluorapatite/hydroxyapatite films. Journal of Biomedical Materials Research: Part B, Applied Biomaterials 2004;69:33-37.

74- Wang Y, Zhang S, Zeng X, Cheng K, Qian M ,Weng W. In-vitro behavior of fluoridated hydroxyapatite coatings in organic-containing simulated body fluid. Materials Science and Engineering C 2007; 27: 244-250.

75- Tomashov ND, Chernova GP, Ruscol YS, Ayuyan GA. The passivation of alloys on titanium bases. Electrochimica Acta 1974;19:159-172.

76- Niinomi M. Recent research and development in titanium alloys for biomedical applications and health care goods. Science and Technology of Advanced Materials. 2003;4:445-454. 